\title{
Barbara Surdykowska
}

Uniwersytet Kardynała Stefana Wyszyńskiego

\section{ROLA ZWIĄZKÓW ZAWODOWYCH W PODNOSZENIU KWALIFIKACJI PRACOWNIKÓW}

Podnoszenie kwalifikacji zawodowych należy postrzegać z perspektywy oddziaływania tego zjawiska na stan gospodarki zarówno w wymiarze makro-, jak i mikroekonomicznym. $Z$ uwagi na to, że wpływ ten jest jednoznacznie pozytywny dla rozwoju elastyczności i konkurencyjności przedsiębiorstw oraz dla samych pracowników, wydaje się wskazane, aby za pomocą norm prawnych stymulować pracodawców do organizacji szkoleń, a pracowników do tego, aby w nich uczestniczyli ${ }^{1}$.

Celem artykułu jest próba odpowiedzi na pytanie, czy jest możliwe w polskich warunkach, zwiększenie zainteresowania partnerów społecznych (związków zawodowych i organizacji pracodawców) negocjowaniem problematyki podnoszenia kwalifikacji. Zdiagnozowanie obecnego poziomu zaangażowania nie wydaje się trudne - w polskim modelu dialogu społecznego negocjowanie tematyki kształcenia ustawicznego na szczeblu centralnym i branżowym występuje rzadko². Wpisuje się to w generalnie niepokojący obraz sytuacji w odniesieniu do tego zagadnienia. Uczestnictwo w kształceniu ustawicznym po-

${ }^{1}$ M. SKąPSKI, Funkcje prawnej regulacji podnoszenia kwalifikacji zawodowych pracowników i zakres ich realizacji w Polsce, [w:] Wspótczesne problemy prawa pracy i ubezpieczeń spolecznych, red. L. FloreK, Ł. PisarczyK, Warszawa 2011, s. 249.

${ }^{2}$ Polacy pracujacy a kryzys fordyzmu, red. J. Gardawski, Warszawa 2009. 
lega na uczestnictwie w różnych formach kształcenia. W literaturze wyróżnia się kształcenie formalne, kształcenie pozaformalne i kształcenie nieformalne ${ }^{3}$. Należy zwrócić uwagę, że Polska charakteryzuje się relatywnie dobrym poziomem wykształcenia ludności w wieku 25-64 oraz bardzo niskim poziomem uczestnictwa w kształceniu ustawicznym ${ }^{4}$. Zgodnie z danymi Eurostatu w 2008 r. 4,7 procent Polaków (w wieku 25-64 lata) uczestniczyło w procesie kształcenia ustawicznego, co powoduje, że Polska znajduje się na jednym z ostatnich miejsc w Europie, znacznie poniżej kryterium 12,5 procent określonym w zakończonej już Strategii Lizbońskiej ${ }^{5}$. Należy także podkreślić, że struktura osób uczestniczących w kształceniu ustawicznym jest bar-

${ }^{3}$ H. DĄBrowski, M. Lis, K. Pogorzelski, Kształcenie ustawiczne w czasie zmian, [w:] Zatrudnienie w Polsce w 2008. Praca w cyklu życia, red. M. Bukowski, Warszawa 2010, s. 152. Kształcenie formalne polega na uczeniu się w systemach szkolnych i systemach szkoleń, które prowadzą do uzyskania kwalifikacji powszechnie uznawanych w danym systemie prawnym (formalnym systemie kwalifikacji); Kształcenie pozaformalne to proces zinstytucjonalizowany, odbywający się jednak poza formalnym systemem zdobywania kwalifikacji. Udział w edukacji tego typu obejmuje wszelkie zorganizowane działania edukacyjne, które nie odpowiadają definicji edukacji szkolnej. Kształcenie pozaformalne prowadzone jest zazwyczaj w formie kursów, szkoleń, instruktaży (w miejscu pracy lub poza praca); Kształcenie nieformalne to proces niezinstytucjonalizowany polegający na samodzielnym uczeniu się. Do metod wykorzystywanych należy np. korzystanie z książek, prasy, telewizji, Internetu, korzystanie z programów komputerowych, korzystanie z pomocy znajomych lub współpracowników. Nauka odbywa się bez nauczyciela.

${ }^{4}$ Należy jednak zwrócić uwagę, że pomimo porównywalnych wskaźników skolaryzacji na poziomie wyższym, pomiędzy Polską a innymi państwami OECD obserwuje się znaczne różnice w zakresie wybieranych kierunków. W Polsce dominują kierunki z zakresu nauk społecznych, biznesu, administracji, nauk humanistycznych i pedagogiki. W 2007 r. tego typu kierunki ukończyło ponad 67\% absolwentów, natomiast kierunki ścisłe i inżynieryjne 17\%. Przykładowo proporcje te w UE 15 wynoszą 56\% i 24\%, w Finlandii 44\% i $28 \%$.

${ }^{5}$ H. Dąbrowski, M. Lis, K. Pogorzelski, op. cit., s. 152. Można także zwrócić uwagę, że najwyższy wskaźnik uczestnictwa w kształceniu ustawicznym ma miejsce w państwach skandynawskich, a także w Szwajcarii i Wielkiej Brytanii. W tych państwach ponad $20 \%$ osób w wieku powyżej 25 lat uczestniczy w różnych formach edukacji. Wśród nowych państw członkowskich najwięcej osób dokształca się w Słowenii (13, 8\%) oraz Estonii (9,8\%). 
dzo zróżnicowana ze względu na ich wykształcenie, wiek i miejsce zamieszkania 6 .

Osoby w wieku powyżej 25 lat podnoszą kwalifikacje zawodowe lub doskonalą inne umiejętności głównie dzięki finansowaniu przez pracodawców (około 40 procent) przede wszystkim różnorodnych kursów. Około 10 procent respondentów uczestniczyło w kursach finansowanych ze środków własnych, około 7 procent uczestniczyło w kursach finansowanych ze środków Europejskiego Funduszu Społecznego, a jedynie 5 procent respondentów wskazało na finansowanie szkoleń z Funduszu Pracy ${ }^{7}$. Charakterystyczny jest niski odsetek respondentów wskazujących na tę ostatnią formę finansowania kształcenia.

Podstawowym problemem w odniesieniu do zaangażowania w kształcenie ustawiczne jest wskazany powyżej niski poziom uczestnictwa. Kolejnym, równie istotnym, jest bardzo wysoki poziom selektywności procesu dokształcania ze względu na: status na rynku pracy (dokształcają się głównie pracujący), wiek (dokształcają się głównie osoby młode), poziom wykształcenia (dokształcają się głownie osoby z wyższym wykształceniem) i miejsce zamieszkania (preferencja dla ośrodków miejskich). Do tego dochodzi zjawisko, polegające na niższym uczestnictwie w podnoszeniu kwalifikacji, charakterystyczne dla pracowników zatrudnionych u małych i średnich pracodawców.

Ważnym elementem budowy sprawnie funkcjonującego modelu uczestnictwa jednostek w procesie kształcenia ustawicznego jest zaangażowanie pracodawców. Jakkolwiek sytuacja na rynku pracy zmienia się i coraz większą rolę odgrywają osoby samozatrudnione, to praca najemna (w relacji pracownik - pracodawca) pozostaje cały czas podstawową formą aktywności zawodowej Polaków. W Polsce udział pracodawców w rozwijaniu kwalifikacji pracowników jest niewiel-

${ }^{6} 57 \%$ dokształcających się ma wykształcenie wyższe lub policealne, około $19 \%$ wykształcenie średnie, $12 \%$ zasadnicze zawodowe a 1,7\% co najwyżej podstawowe. Jedynie co piąta osoba podnosząca swoje kwalifikacje mieszka na wsi, a ponad połowę stanowią mieszkańcy miast ponad 200 tys. osób. Osoby dokształcające się to głownie osoby młode - 47\% jest w wieku 25-34 lata. Diagnoza społeczna 2009. Warunki i jakość życia Polaków, red. J. CzAPIŃSKI, T. PANEK.

${ }^{7}$ Diagnoza społeczna 2009... 
ki, szczególnie w zakresie organizowania szkoleń w zakładach pracy. W 2005 r. tego typu działania odbywały się tylko $\mathrm{w}$ około $1 / 3$ polskich przedsiębiorstw (średnia w 27 UE to 60 procent) i w zaledwie $1 / 5$ firm zatrudniających od 10 do 19 pracowników (średnia 27 UE 27 to 49 procent). W przypadku pracodawców zatrudniających powyżej 250 pracowników różnica pomiędzy Polską a średnią unijną jest mniejsza, choć też wyraźna. W Polsce szkolenia organizuje 80 procent takich pracodawców, natomiast w UE - 91 procent. W konsekwencji w polskich przedsiębiorstwach szkoli się 21 procent ogółu zatrudnionych (przy średniej 27 UE około 30 procent) ${ }^{8}$.

Niewielkie zaangażowanie polskich pracodawców wynika z niedostrzegania korzyści z podnoszenia kwalifikacji pracowników. Przyznają to także organizacje pracodawców. Według raportu przygotowanego dla Pracodawców RP głównym powodem, dla którego przedsiębiorstwa nie angażują się w rozwój swoich kadr, jest przekonanie o wystarczającym dopasowaniu kompetencji pracowników do potrzeb firmy ${ }^{9}$. Badania Eurostatu pokazują, że brak szkoleń w polskich firmach to bardziej efekt braku świadomości wśród kadry zarządzającej niż braku środków. 80 procent polskich firm, które nie prowadzą szkoleń, wskazało, że przyczyną tego jest ocena, iż obecne kwalifikacje personelu odpowiadają w pełni potrzebom przedsiębiorstwa, 58 procent respondentów stwierdzało, że zatrudnili pracowników o odpowiednich kwalifikacjach, a zaledwie 29 procent jako przyczynę braku organizowania szkoleń wskazało, że byłoby to zbyt obciążające finansowo ${ }^{10}$. W literaturze zwraca się uwagę, że dużym ograniczeniem inwestowania w pracowników przez polskich pracodawców są barie-

${ }^{8}$ H. Dąbrowski, M. Lis, K. Pogorzelski, op. cit., s. 153.

9 Pracodawcy a podnoszenie kompetencji zawodowych pracowników. Analiza wyników badań ankietowych przeprowadzonych wśród przedsiębiorców w ramach projektu Obserwatorium Regionalnych Rynków Pracy Pracodawców Rzeczypospolitej Polskiej, Raport z badań pracodawców, VII, Kraków-Warszawa 2010, s. 8.

10 H. Dąbrowski, M. Lis, K. Pogorzelski, op. cit., s. 155; Fundacja Obserwatorium Zarzadzania, Szkolenia w Polsce 2007, Warszawa 2007. 
ry informacyjne spowodowane paradoksalnie znaczną liczbą instytucji edukacyjnych przy braku możliwości oceny jakości ich oferty ${ }^{11}$.

W literaturze wskazuje się na wiele argumentów przemawiających przeciwko dotychczasowemu modelowi prowadzonej w Polsce polityki wspierania kształcenia ustawicznego. Pisze się, że o jej nieskuteczności świadczy chociażby to, że pomimo ogromnych środków przeznaczonych na dofinansowanie edukacji dorosłych (ponad 12 miliardów złotych w latach 2006-2008) wskaźnik uczestnictwa w kształceniu ustawicznym nie uległ istotnej zmianie i w 2008 r. był na takim samym poziomie jak w 2004 r. Wskazuje się, że nieprawidłowe jest kierowanie wsparcia przede wszystkim do instytucji edukacyjnych. Podstawową wadą takiego rozwiązania jest arbitralność alokacji środków publicznych - brakuje mechanizmu powodującego, że środki kierowane są do najlepszych instytucji edukacyjnych. Alokacja środków jest niezależna od struktury popytu ze strony samych uczestników kształcenia. Innym negatywnym skutkiem kierowania środków do podażowej strony sytemu jest niedopasowanie oferty instytucji szkoleniowych do potrzeb rynku pracy ${ }^{12}$. Na liczne nieprawidłowości wskazuje także Najwyższa Izba Kontroli ${ }^{13}$. Podsumowując, można wskazać na brak wsparcia samych uczestników kształcenia ze strony państwa.

${ }^{11}$ M. Boni, Instytucje edukacji pozaszkolnej [w:] Edukacja dla pracy. Raport o rozwoju społecznym, red. U. SzTAnderska, E., Drogosz-ZabŁocka, B. Minkiewicz, Warszawa 2007; Inwestycja w kadry: perspektywa matych i średnich przedsiębiorstw, red. O. Konieczny, R. SchmidtKe, Katowice 2007; PSDB spótka z o.o., Ocena wptywu funduszy strukturalnych na zwiększenie konkurencyjności przedsiębiorstw, Warszawa 2008.

12 H. Dąbrowski, M. Lis, K. Pogorzelski, op. cit., s. 175.

13 Najwyższa Izba Kontroli, Informacja o wynikach kontroli kształcenia osób dorosłych na tle potrzeb rynku pracy. NIK wskazuje, że 53\% słuchaczy szkół dla dorosłych w roku akademickim 2007/2008 kształciło się w 20 zawodach o największej liczbie bezrobotnych absolwentów, 35,6\% zawodów nauczanych w badanych placówkach należało do zawodów stale nadwyżkowych (w których liczba bezrobotnych zarejestrowanych w urzędach pracy jest większa ponad 10\% niż liczba zarejestrowanych ofert pracy); jedynie 12,5\% kształconych zawodów należało do tzw. zawodów deficytowych (w których liczba bezrobotnych zarejestrowanych w urzędach pracy jest 
I. PoDNOSZENIE KWALIFIKACJI ZAWODOWYCH W REGULACJACH PRAWNYCH

Zgodnie z art. $103^{1}$ k.p. przez podnoszenie kwalifikacji zawodowych rozumie się zdobywanie lub uzupełnianie wiedzy i umiejętności przez pracownika z inicjatywy pracodawcy albo za jego zgodą ${ }^{14}$. Pracownikowi podnoszącemu kwalifikacje zawodowe przysługuje urlop szkoleniowy oraz zwolnienie z całości lub części dnia pracy na czas niezbędny by punktualnie przybyć na obowiązkowe zajęcia oraz na czas ich trwania. Zgodnie $\mathrm{z}$ art. $103^{6}$ k.p. pracownikowi zdobywającemu lub uzupełniającemu wiedzę i umiejętności na zasadach innych, niż określone $\mathrm{w}$ art. $103^{1}-103^{5} \mathrm{k}$.p, mogą być przyznane zwolnienie $\mathrm{z}$ całości lub części dni pracy bez zachowania prawa do wynagrodzenia oraz urlop bezpłatny $\mathrm{w}$ wymiarze ustalonym w porozumieniu między pracodawcą a pracownikiem.

Przy skrótowym omawianiu polskich ram prawnych dotyczących tej problematyki należy zwrócić przede wszystkim uwagę na art. 67 ustawy o promocji zatrudnienia i instytucjach rynku pracy, przewidujący możliwość powołania funduszu szkoleniowego. W literaturze zwraca się uwagę na zdawkowość regulacji prawnej w odniesieniu do tej problematyki ${ }^{15}$. Z kolei art. 69 ustawy o promocji zatrudnienia i instytucjach rynku pracy przewiduje możliwość częściowej refundacji kosztów szkoleń ze środków Funduszu Pracy. Należy zwrócić także uwagę na art. 43 ustawy pozwalający staroście skierować pracowników w okresie wypowiedzenia, pracowników zatrudnionych u pracodawcy, wobec którego ogłoszono upadłość lub który jest w stanie likwidacji, oraz pracowników i osoby wykonujące inną prace zarobkową lub działalność gospodarczą w wieku 45 plus na szkolenia finansowane ze środków Funduszu Pracy.

mniejsza o ponad $10 \%$ niż liczba ofert pracy). Kontrola wykazała również bardzo niską frekwencję uczestników podczas zajęć i masową rezygnację z udziału w kształceniu.

${ }^{14}$ A. Dral, Podnoszenie kwalifikacji zawodowych przez pracowników z inicjatywy lub za zgoda pracodawcy, «MPP»11/2010; A. WIĄCEK, Podnoszenie kwalifikacji zawodowych w znowelizowanym kodeksie pracy, «PiZS» 9/2010.

15 Ustawa o promocji zatrudnienia i instytucjach rynku pracy, red. Z. GóRAL, Warszawa 2011, s. 427. 
Kwestią, której chciałabym poświęcić więcej uwagi, jest znaczenie zasady wyrażonej w art. 17 k.p. wskazującej, iż pracodawca ma obowiązek ułatwiania pracownikom podnoszenia kwalifikacji zawodowych. Konsekwencją zasady wyrażonej przez ustawodawcę w art. 17 jest art. 94 pkt 4 k.p. mówiący o obowiązku pracodawcy ułatwiania pracownikom podnoszenia kwalifikacji zawodowych. Ustawodawca nie nakłada na pracodawcę obowiązku podjęcia inicjatywy podwyższania kwalifikacji zawodowych pracowników. Spoczywa na nim jedynie obowiązek ułatwiania pracownikom dokształcania. Przez ułatwianie należy rozumieć w szczególności tworzenie pozytywnej atmosfery wobec uczących się pracowników oraz nieodmawianie bez uzasadnionych przyczyn zgody na korzystanie z wybranych przez pracownika form kształcenia ${ }^{16}$. W literaturze zwraca się uwagę, że przepisy kodeksu pracy nie wymagają od pracodawcy, aby tworzył system podnoszenia kwalifikacji przez zatrudnianych pracowników, pozostawiając to ich swobodnemu wyborowi ${ }^{17}$. Sąd Najwyższy wskazuje, że pracodawca nie ma obowiązku zadbania o przystapienie pracownika we właściwym czasie do egzaminów, od wyniku których zależy możliwość kontynuowania dotychczasowej pracy ${ }^{18}$. M. Włodarczyk wskazuje, że niezależnie od tego, czy pracownik podejmuje naukę na skutek skierowania go tam przez pracodawcę, czy też samorzutnie bez skierowania, pracodawca nie może podejmować działań, które można by ocenić jako mające na celu utrudnienie pracownikowi realizacji takich planów ${ }^{19}$.

B. Ćwiertniak wskazuje, że zasada z art. 17 k.p. była w ostatnich latach przedmiotem sporu o charakterze ideologicznym, gdyż środowiska liberalne i neoliberalne wskazywały, że stanowi ona (obok zasady

${ }^{16}$ A. WIĘCEK, Prawne formy podnoszenia kwalifikacji zawodowych pracowników, «PiZS» 9/2009, s. 28.

17 D. Pogorzelska, Podnoszenie kwalifikacji zawodowych w prawie międzynarodowym, europejskim i na gruncie prawa polskiego, «PiZS» 2/2002, s. 12.

${ }_{18}$ Wyrok SN z 6 października 1998 r., I PKN 368/98, «OSNAP» 21/1999, poz. 685.

${ }^{19}$ M. WŁodarczyK., Glosa do uchwały SN z 10 marca 2005 r., II PZP 2/05, «OSP» 6/2006, poz 76 . 
wynikającej z art. 16 k.p.) swoisty relikt poprzedniego systemu ${ }^{20}$. Co ciekawe, projekt kodeksu pracy Komisji Kodyfikacyjnej Prawa Pracy nie przewiduje takiej zasady wśród projektowanych podstawowych zasad prawa pracy. Projektowany art. 145, dotyczący obowiązków pracodawcy, w $\S 1$ pkt 7 wskazuje, że pracodawca jest obowiązany w szczególności ułatwiać pracownikom - w miarę możliwości - podnoszenie kwalifikacji zawodowych.

W doktrynie prawa pracy niemal powszechnie prezentowany jest pogląd, że wskazany w artykule 17. k.p. (i powtórzony w takiej samej formie w art. 94 pkt 6 k.p.) obowiązek pracodawcy ułatwiania pracownikom podnoszenia kwalifikacji zawodowych nie ma charakteru bezwzględnego i nie może stanowić podstawy roszczenia pracownika względem pracodawcy ${ }^{21}$. E. Engel-Babska podkreśla, że analiza przepisów kodeksu pracy nie prowadzi do wniosku, iż w przepisie szczególnym (art. 94 pkt 6 k.p.) doszło do przekształcenia podstawowej zasady prawa pracy zawartej w art. 17 k.p. w roszczenie pracownika ${ }^{22}$.

M. Skąpski podkreśla, że obowiązek ułatwiania pracownikom podnoszenia kwalifikacji zawodowych ma charakter bezwzględny, po-

${ }^{20}$ B. Ćniertniak, Zasady prawa pracy, [w:] Prawo pracy, red. K.W. Baran, Kraków 2005, s. 74.

21 Przykładowo: T. Liszcz, Prawo pracy, Warszawa 2005, s 252; L., Florek, T., Zieliński, Prawo pracy, Warszawa 2004, s. 155; M. WAndzel, [w:] Kodeks pracy. Komentarz, red. B. WAGner, Gdańsk 2007, s. 61; K. RĄCZKA, [w:] Kodeks pracy. Komentarz, red. Z. SALWA, Warszawa 2007, s. 58.

22 E. Engel-BABSKA, glosa do wyroku SN z 25 maja 2000 r., I PKN 657/99, «OSP» 6/2002, poz. 89. Zdaniem autorki o roszczeniu można mówić jedynie wtedy, gdy przepis w sposób jednoznaczny określa dane uprawnienie. Przepis art. 94 pkt 6 k.p. nie dość, że używa pojęcia bardzo ogólnego, co uniemożliwia precyzyjne określenie jego zakresu i charakteru, ale nie określa nadto, co w przypadku, gdy pracodawca nie wykonuje obowiązku ułatwiania podnoszenia kwalifikacji zawodowych pracownika. Autorka podkreśla, że konsekwencją jej stanowiska jest podważanie zasadności wprowadzania do tekstów prawnych przepisów niekorespondujących z normami sankcjonującymi. Brak roszczenia ze strony pracownika do określonego zachowania się pracodawcy czyni ustawowe przepisy, zarówno art. 17 k.p., jak i 94 pkt 6 k.p., pozbawionymi jakiejkolwiek doniosłości prawnej. Co ciekawe, autorka stoi na stanowisku, że inna interpretacja wskazanych przepisów mogłaby prowadzić do paraliżu działalności $\mathrm{u}$ pracodawcy. 
nieważ w art. 17 ustawodawca nie posługuje się sformułowaniem „stosownie do możliwości i warunków”, którego używa, definiując obowiązek zaspokajania bytowych, socjalnych i kulturalnych potrzeb pracowników (art. 16 k.p.). Zdaniem autora w ramach realizacji obowiązku z art. 17 k.p. pracodawca powinien zastosować wszelkie rozwiązania organizacyjne, umożliwiające odbywanie zajęć pracownikowi samodzielnie podnoszącemu kwalifikacje w granicach, w jakich nie wywołuje to kolizji z tokiem pracy zakładu i obowiązkami pracowniczymi danej osoby. M. Skąpski podkreśla jednak, że możliwość dochodzenia roszczeń o ułatwienie podnoszenia kwalifikacji w drodze powództwa wydaje się słabym zabezpieczeniem pracowniczych interesów na tym polu ${ }^{23}$.

W doktrynie pojawiają się opinie, że obowiązek nałożony na pracodawcę w art. 94 pkt 6 k.p. nie ma charakteru zobowiązania wobec indywidualnego pracownika, a jest zobowiązaniem wobec załogi. Sankcji za jego nieprzestrzeganie należy więc upatrywać w zbiorowym prawie pracy (egzekwowaniem tego obowiązku powinny się zająć organizacje związkowe $)^{24}$. Ten pogląd jest istotny dla dalszych rozważań.

Sąd Najwyższy podkreśla, że dbałość o zawodowe kwalifikacje jest w warunkach gospodarki wolnorynkowej sprawą samych zainteresowanych, warunkującą ich funkcjonowanie na rynku pracy. Zdobycie lub podwyższanie kwalifikacji zawodowych stało się cennym dobrem o wymiernej wartości na rynku pracy, wobec czego sami pracownicy są skłonni troszczyć się o ich zdobywanie lub podwyższanie. To pracownik powinien być zainteresowany podwyższaniem swoich kwalifikacji, a w związku z tym przejawiać w tym kierunku inicjatywę i zaangażowanie, pracodawca ma zaś jedynie obowiązek mu to ułatwiać ${ }^{25}$.

Zadaniem SN było odniesienie się do określonego stanu faktycznego. Tak więc niejako na marginesie tego orzeczenia można zauważyć, że taka wizja uczestnictwa w kształceniu ustawicznym pracowników

23 M. SKĄPSKI, Funkcje prawnej regulacji..., s. 252.

24 J. Wratny, Kodeks pracy. Komentarz, Warszawa 2005, s. 266; A. Patulski, [w:], Kodeks pracy z komentarzem, red. W. Musialski, A. NaŁęCz, G. OrŁowski, A. Patulski, W. Patulski, Gdańsk 1998, s. 196.

${ }^{25}$ Wyrok NS z 25 maja 2000 r., I PKN 657/99, «OSP» 6/2002, poz. 89. 
nie dostrzega faktu istnienia tzw. grup problemowych - pracowników starszych, gorzej wykształconych, zatrudnionych w małych i średnich przedsiębiorstwach - które mają utrudniony dostęp do szkoleńn ${ }^{26}$. Ze względów makroekonomicznych i ogólnospołecznych udział tych grup w szkoleniach jest jednakże kluczowy.

Podsumowując, można odwołać się do poglądu Z. Górala, który wskazuje, że ułatwianie podnoszenia kwalifikacji zawodowych może stanowić tylko przedmiot ustaleń między partnerami społecznymi, do których to ustaleń dochodzi w drodze rokowań zbiorowych, bądź też być przedmiotem swobodnie zawieranej między stronami stosunku pracy umowy o podnoszenie kwalifikacji zawodowych ${ }^{27}$.

\section{PoDNOSZENIE KWALIFIKACJI A ZWIĄZKI ZAWODOWE}

Przystępując do uwag dotyczących roli partnerów społecznych w podnoszeniu kwalifikacji zawodowych w Polsce, chciałabym na wstępie wskazać regulacje zawarte w Konwencji nr 142 Międzynarodowej Organizacji Pracy dotyczącej roli poradnictwa i kształcenia zawodowego w rozwoju zasobów ludzkich ${ }^{28}$ oraz konwencji nr 140 MOP dotyczącej płatnego urlopu szkoleniowego ${ }^{29}$. Oba te akty odwołują się do roli partnerów społecznych - w art. 5 Konwencji nr 142 wskazuje się, że polityka oraz programy poradnictwa i kształcenia zawodowego winny być opracowywane i stosowane przy współpracy z organizacjami pracodawców i pracowników (oraz innymi zainteresowanymi instytucjami). Podobnie w art. 6 Konwencji nr 140 podkreśla się rolę związków zawodowych i organizacji pracodawców w popieraniu płatnego urlopu szkoleniowego. Wśród aktów MOP, poruszających

26 B. Surdykowska, Podnoszenie kwalifikacji zawodowych - wyzwanie dla partnerów społecznych, «Kontrola Państwowa», 2/2010, s. 122.

27 Z. Góral, O kodeksowym katalogu zasad indywidualnego prawa pracy, Warszawa 2011, s. 200.

${ }^{28}$ Konwencja MOP nr 142 dotycząca roli poradnictwa i kształcenia zawodowego w rozwoju zasobów ludzkich z 4 czerwca 1975 r., ratyfikowana przez Polskę, Dz.U. z 1979 r. Nr 29, poz. 164.

${ }^{29}$ Konwencja MOP nr 140 dotycząca płatnego urlopu szkoleniowego z 5 czerwca 1974 r., ratyfikowana przez Polskę, Dz.U. z 1979 r. Nr 16, poz. 100. 
problematykę roli partnerów społecznych w sferze podnoszenia kwalifikacji zawodowych, główny nacisk na to zagadnienie położony został w Zaleceniu nr 195 dotyczącym zasobów ludzkich: kształcenie, szkolenie i uczenie się przez całe życie ${ }^{30}$. W ust. 1 Zalecenia wskazuje się, że państwa członkowskie MOP powinny w oparciu o dialog społeczny przygotować, stosować i dokonywać przeglądu krajowych polityk rozwoju zasobów ludzkich, polityki edukacyjnej, szkoleniowej oraz uczenia się przez całe życie. Polityka ta powinna być spójna z polityką gospodarczą, fiskalną i społeczną. W Zaleceniu podkreśla się (art. 5), że państwa członkowskie powinny rozwijać dialog społeczny oraz rokowania zbiorowe w obszarze szkolenia na wszystkich poziomach (międzynarodowym, krajowym, branżowym i na poziomie poszczególnych zakładów pracy). Rola partnerów społecznych dostrzegana jest także w sferze rozwoju kompetencji (art. 9 pkt a, b, c) w odniesieniu zarówno do uznawania i dokumentowania umiejętności (art. 11 pkt 1), jak i do instytucji szkoleniowych (art. 14 pkt b i art. 15 pkt c). Ważne jest, że podkreśla się rolę partnerów społecznych w procesie wspierania - przy zastosowaniu strategii rozwoju zasobów ludzkich - integracji zawodowej osób bezrobotnych oraz osób o szczególnych potrzebach w zakresie zatrudnienia.

Zagadnieniem, które wywołuje duże rozbieżności w literaturze, jest relacja pomiędzy aktywnością związków zawodowych a szkoleniami pracowników. Zależność pomiędzy obecnością i siłą związków zawodowych a zaangażowaniem pracodawców i pracowników w szkolenia i podnoszenie kwalifikacji zawodowych jest złożona i wielu autorów, analizując dane na poziomie poszczególnych zakładów pracy czy branży w różnych okresach i poszczególnych państwach, dochodzi do przeciwstawnych wniosków.

Prace amerykańskich badaczy z lat 80. ubiegłego wieku wskazują negatywny wpływ uzwiązkowienia na poziom zaangażowania pracowników i pracodawców w podnoszenie kwalifikacji zawodowych ${ }^{31}$. Inne

30 Zalecenie MOP z 1 czerwca 2004 r. Nr 195 dotyczące rozwoju zasobów ludzkich: kształcenie, szkolenie i uczenie się przez całe życie.

31 G. Duncan, F. Stafford, Do Union Members Receive Compensating Differentials, «American Economic Review», 30.7/1980, s. 355-71; J. Mincer, Union Effects on 
wyniki badań podają prace L. Lyncha ${ }^{32}$, który wykazuje pozytywną relację pomiędzy obecnością związków zawodowych a poziomem szkoleń, oraz ustalenia S. Kennedy'ego ${ }^{33}$ z zespołem, który wskazuje na fakt, że u tych pracodawców, u których związki zawodowe intensywnie negocjują, liczba szkoleń jest większa (nie ma natomiast statystycznie znaczącej relacji pomiędzy samym poziomem uzwiązkowienia a liczbą szkoleń). Także opracowanie F. Greena ${ }^{34}$ przedstawia, że istnieje zależność pomiędzy obecnością związków zawodowych u mniejszych pracodawców w Wielkiej Brytanii a liczbą szkoleń.

W latach 90. XX w. dominują prace, w których autorzy dochodzą do wniosku o istnieniu pozytywnej relacji pomiędzy obecnością związków zawodowych a dostępem pracowników do szkoleńn ${ }^{35}$. W kilku pracach jednak autorzy takiej relacji nie dostrzegają ${ }^{36}$.

Wages, Turnover and Job Training, «Research in Labour Economics» 2/1983, s. 217; J. BARron, M.A. Loewenstein, Employer Size: The Implications for Search, Training, Capital Investment, Starting Wages and Wage Growth, «Journal of Labor Economics» 5.1/1987, s. 76-89.

${ }^{32}$ L. LyNCH, Private Sector Training and the Earning of Young Workers, «American Economic Review» 82/1992, s. 299-312.

33 S. Kennedy, R. Drago, J. Sloan, M. Wooden, Vision of Training: Australian evidence, «Journal of Industrial Relations» 32.4/1990, s. 565-80.

${ }^{34}$ F. Green, The Determinants of Training of Male and Female Employees in Britain, «Oxford Bulletin of Economics and Statistics»55.1/1993, s. 103-122.

35 J. Veum, Sources of Training and Their impact on Wages, «Industrial and Labour Relations Review» 48.4/1995, s. 812-826; A. Воотн, Job-Related Formal training: Who Receives It And What Is It Worth?, «Oxford Bulletin of Economics and Statistics» 53/1991, s. 281-294; C. Greenhalgh, G. Mavrotas, The Role of career Aspirations and Financial Constraints in Individual Access to Vocational training, «Oxford Economic Papers» 46/1994, s. 579-604; W. Arulampalam, A. Bоoth, Labour Market Flexibility and Skills Acquisition: Is There a Trade - off?, «British Journal of Industrial Relations» 36.4/1998, s. 521-536; F. Green, S. Machin, D. Wilkinson, Trade Unions and Training Practices in British Workplaces, «Industrial and Labour Relations Review» 52.2/1999, s. 179-95; A. Booth, M. Francesconi, G. Zoega, Unions, Work-Related Training and Wages: Evidence for British Men, «Industrial and Labor Relations Review» 57.1/2003, s. 68-91.

${ }^{36}$ S. BLACK, L. LynCH, Determinant of Employment- Provided Training, «Industrial and Labor relations Review» 51/1998, s. 365-381; D. Green, T. Lamieux, The Impact 
Badania OECD wyraźnie pokazują, że w tych państwach, w których problematyka szkoleń jest szeroko poruszana w porozumieniach zbiorowych zawieranych ze związkami zawodowymi lub stanowi przedmiot negocjacji z przedstawicielstwami pracowniczymi, dostęp pracowników do szkoleń jest szerszy ${ }^{37}$.

Podstawową rolą związków zawodowych jest niewątpliwie negocjowanie porozumień zbiorowych i układów zbiorowych pracy. Obecność problematyki szkoleń, podnoszenia kwalifikacji i rozwoju zawodowego w porozumieniach zbiorowych w poszczególnych państwach różni się znacznie ${ }^{38}$. Na zakres podejmowania w rokowaniach zbiorowych wskazanej problematyki wywiera wpływ charakter relacji przemysłowych w danym państwie i system edukacji powszechnej. Dostrzega się jednak wyraźne zwiększenie zainteresowania tą problematyką od połowy lat 90. ubiegłego wieku ${ }^{39}$.

Z badań przeprowadzonych w 1999 r. w państwach 15 UE wynika, że pracodawcy w większym stopniu angażowali się w kształcenie pracowników, gdy zawarto porozumienie dotyczące tej problematyki w podnoszenie kwalifikacji pracowników zaangażowanych było 34 procent przedsiębiorstw, w których nie było porozumienia, i 52 procent przedsiębiorstw, w których było porozumienie. Fakt zawarcia porozumienia zwiększał średnio o 18 procent szansę na aktywność pracodawcy w tym zakresie ${ }^{40}$.

of Unionization on the Incidence of the Sources of Payment for Training in Canada: a study based on the adult education and training survey, [miejsce wydania] 2001.

${ }^{37}$ OECD, Employment Outlook, Paris, 2003.

${ }^{38}$ Lifelong Learning and Collective Bargaining, An analysis of EIRO articles, European Foundation for the Improvement of Living and Working Condition, 2002, s. 5.

${ }^{39}$ Lifelong Learning and Collective Bargaining, An analysis of EIRO articles, European Foundation for the Improvement of Living and Working Condition, 2002, s. 6.

${ }^{40}$ Contribution of collective bargaining to continuing vocational training, European Foundation for the Improvement of Living and Working Conditions, CEDEFOP (European Center for the Development of Vocational Training), 2009, s. 28. 
Państwa członkowskie UE można podzielić na kilka grup. Pierwsza grupa to państwa, w których rokowania dotyczące problematyki podnoszenia kwalifikacji prawie nie występują (Polska, Cypr). Druga grupa krajów to te, w których dominują porozumienia zawierane na poziomie zakładu pracy, ze względu na generalną praktykę rokowań zbiorowych (Węgry, Łotwa, Wielka Brytania), bądź ze względu na tradycję regulowania zagadnienia dostępu do kształcenia w porozumieniach zakładowych (Słowacja). Następnie, są państwa takie jak Niemcy, w których przeważają porozumienia na poziomie sektorowym. Można również wyróżnić państwa, w których w zakresie omawianej problematyki dominują międzysektorowe porozumienia zbiorowe (np. Belgia, Finlandia, Irlandia). Wreszcie jest grupa państw, w których wykształciła się praktyka zawierania układów zbiorowych pracy na poziomie centralnym, co dotyczy także kwestii podnoszenia kwalifikacji zawodowych (np. Bułgaria, Holandia, Dania czy Hiszpania) ${ }^{41}$.

Wydaje się, że w Polsce wciąż nie dostrzega się możliwości, które daje zaangażowanie partnerów społecznych w zarządzanie sektorowymi lub międzysektorowymi funduszami szkoleniowymi. Sektorowe fundusze szkoleniowe istnieją w wielu krajach europejskich i finansowane są z obligatoryjnych składek wliczanych w koszty pracy ${ }^{42}$. Dochodzą do tego dodatkowe źródła finansowania (budżetowe, europejskie fundusze strukturalne), ale $\mathrm{z}$ reguły nie przekraczają $25 \%$ całości budżetu takiego funduszu ${ }^{43}$. W większości państw nie ma powiązania między tą obowiązkową składką a podejmowaniem przez pracodawcę własnych działań w zakresie szkolenia pracowników.

Różny jest podmiotowy zakres działania takich funduszy. Mają one charakter bądź sektorowy - dla konkretnej branży, dla kilku branż lub generalnie międzybranżowy. Sektorowe fundusze szkoleniowe zarządzane są bądź dwustronnie przez organizacje pracodawców i związki

${ }^{41}$ Contribution of collective bargaining to continuing vocational training, European Foundation for the Improvement of Living and Working Conditions, CEDEFOP (European Center for the Development of Vocational Training), 2009, s. 14.

42 Ich wysokość wynosi od 0,1do 2,5\% funduszu płac.

${ }^{43}$ Sectoral training funds in Europe, CEDEFOP, Luxemburg, Office for Official Publications of the European Communities, 2008, s. 14. 
zawodowe, bądź trójstronnie $\mathrm{z}$ udziałem przedstawicieli administracji publicznej. Fundusze w większości przypadków finansują bezpośrednie koszty szkoleń, w niektórych przypadkach także koszty pośrednie - związane np. z dojazdem pracownika i zakwaterowaniem w miejscu szkolenia bądź z kosztami pracy pracownika zastępującego w miejscu pracy pracownika uczestniczącego w podnoszeniu kwalifikacji. Większość sektorowych funduszy szkoleniowych pełni także ważną rolę doradczą. Pomaga pracodawcom opracowywać analizy potrzeb szkoleniowych i wynikające z nich plany szkoleniowe dla zatrudnionych pracowników ${ }^{44}$.

Jednym z głównych zadań sektorowych funduszy szkoleniowych jest taka redystrybucja środków, aby trafiały one także do pracowników gorzej wykształconych, starszych czy emigrantów (wszelkie badania pokazują, że są to grupy w mniejszym stopniu uczestniczące w szkoleniach). Kolejną, „poszkodowaną” grupą pracowników są pracownicy małych i średnich przedsiębiorstw. Jakkolwiek sektorowe fundusze szkoleniowe w większości analizowanych przypadków stawiają sobie za cel zwiększenie udziału pracowników zatrudnionych w małych i średnich przedsiębiorstwach w szkoleniach, jest to cały czas problem nie w pełni rozwiązany.

W literaturze podkreśla się zalety funkcjonowania sektorowych funduszy szkoleniowych ${ }^{45}$. Wskazuje się między innymi na:

- ich rolę we wzmacnianiu współpracy między organizacjami pracodawców a związkami zawodowymi i generalnie pozytywny wpływ na rozwój dialogu społecznego;

- zabezpieczanie ciagłości finansowania szkoleń;

- spełnianie funkcji ogólnospołecznej poprzez ułatwianie dostępu do szkoleń pracowników niskowykwalifikowanych, starszych, emigrantów oraz (aczkolwiek tu osiagnięcia nie są w pełni satysfakcjonujące) pracowników małych i średnich przedsiębiorstw;

44 Sectoral training funds in Europe, CEDEFOP, Luxemburg, Office for Official Publications of the European Communities, 2008, s. 14.

${ }^{4}$ Sectoral training funds in Europe, CEDEFOP, Luxemburg, Office for Official Publications of the European Communities, 2008, s. 15. 
- opracowywanie programów szkoleniowych dostosowanych do potrzeb branż;

- prowadzenie działalności eksperckiej w zakresie analizy potrzeb szkoleniowych w poszczególnych branżach, analizy potrzeb w zakresie przyszłych kwalifikacji czy działań dotyczących promocji określonych zawodów, co istotne, przy współudziale stron bezpośrednio zaangażowanych, jakimi są organizacje pracodawców i związki zawodowe.

Należy jeszcze zwrócić uwagę na udział partnerów społecznych w wyznaczaniu celów dotyczących kształcenia ustawicznego. Zaangażowanie związków zawodowych i organizacji pracodawców w szeroko rozumianą problematykę kształcenia ustawicznego jest różne w poszczególnych państwach członkowskich. Zależy to od charakterystyki stosunków przemysłowych w poszczególnych państwach i siły partnerów społecznych. Możemy mieć do czynienia z działaniami dwustronnymi bądź trójstronnymi z udziałem administracji publicznej na poziomie centralnym, regionalnym lub branżowym ${ }^{46}$. Działania moga dotyczyć także transparentności sytemu kwalifikacji zawodowych, współpracy ze stroną rządową przy tworzeniu narodowych ram kwalifikacyjnych czy działań z zakresu egzaminów zawodowych.

\section{ROLA PARTNERÓW SPOŁECZNYCH - POLSKIE UWARUNKOWANIA}

Układy zbiorowe pracy, czyli porozumienia normatywne zawierane przez związki zawodowe z pracodawcami w sprawie szeroko pojmowanych warunków pracy i płacy, stanowią w polskiej rzeczywistości niedocenianą płaszczyznę możliwości oddziaływania na podnoszenie kwalifikacji zawodowych przez pracowników. Postanowienia dotyczące uprawnień związanych z podnoszeniem kwalifikacji zawodowych mogłyby znaleźć się w pozapłacowych postanowieniach części norma-

${ }^{46}$ Contribution of collective bargaining to continuing vocational training, European Foundation for the Improvement of Living and Working Conditions, CEDEFOP (European Center for the Development of Vocational Training), 2009, s. 10. 
tywnej układu zbiorowego pracy ${ }^{47}$. W literaturze wskazuje się, że do pozapłacowych postanowień układów zbiorowych pracy można zaliczyć postanowienia dotyczące prawa do ponownego zatrudnienia (np. obowiązku pracodawcy zawiadomienia byłych pracowników o zamiarze zatrudnienia pracowników w ramach tej samej grupy zawodowej) lub prowadzenia banku rezerw kadrowych, określenia zasad polityki awansowej, czasu pracy (np. przerw w pracy), urlopów (np. dodatkowych, okolicznościowych, szkoleniowych), ochrony pracy kobiet i młodocianych, bezpieczeństwa i higieny pracy (np. środków ochrony osobistej $)^{48}$. Jak widać, jedno ze wskazanych powyżej postanowień dotyczy interesującej nas problematyki podnoszenia kwalifikacji zawodowych (urlopów szkoleniowych). Należy jednak zauważyć, że w większości opracowań nie uwypukla się możliwości zawarcia w części normatywnej układów zbiorowych pracy postanowień związanych z szeroko rozumianą sferą podnoszenia kwalifikacji zawodowych.

W części obligacyjnej układu zbiorowego pracy mogą zostać zawarte normy dotyczące utworzenia zakładowego funduszu szkoleniowego oraz wysokość odpisu na fundusz szkoleniowy ${ }^{49}$. Mogą zostać określone także zasady dotyczące udziału związków zawodowych w tworzeniu planów szkoleniowych oraz reguły wydatkowania środków zgromadzonych w funduszu szkoleniowym.

W tym miejscu należy odwołać się do wcześniejszych rozważań, dotyczących znaczenia zasady prawa pracy wyrażonej w art. 17 k.p.

${ }^{47} \mathrm{~W}$ literaturze zwraca się uwagę na zwiększanie się roli pozapłacowych postanowień zawartych w układach zbiorowych pracy, np. C. RodRIGEz D'AcRIS, A. Johnson, A. KorNelakis, Zagadnienia pozapłacowe w układach zbiorowych. Austria, Grecja, Włochy, «Dialog. Pismo dialogu społecznego»3/2011, s. 5 i n.

${ }^{48}$ K. Baran, Zbiorowe prawo pracy, Kraków 2002, s. 56.

49 Wyniki badań dotyczących treści części obligacyjnej układu zbiorowego pracy przedstawia B. Skulimowska. Autorka wskazuje, że w jednym układzie zbiorowym pracy zawartym w branży podlegającej głębokim przekształceniom restrukturyzacyjnym znalazła zapis dotyczący udziału związków zawodowych w opracowywaniu okresowych planów pozwalających dostosować kwalifikacje pracowników do oczekiwań pracodawców, B. SкuLImowsKa, Postanowienia obligacyjne układów zbiorowych pracy, [w:] Uktady zbiorowe w demokratycznym ustroju pracy, red. J. WRATNY, Warszawa 1997, s. 172. 
i wypływającego z niej obowiązku pracodawcy (art. 94 pkt 6 k.p.). Stanowisko większości autorów można by podsumować w sposób następujący - „ułatwianie”, o którym mowa w kodeksie pracy, polega na tym, by pracodawca „nie przeszkadzał” pracownikowi w podnoszeniu kwalifikacji. W sytuacji, w której nie dochodzi do podnoszenia kwalifikacji ani z inicjatywy, ani za zgodą pracodawcy, (regulacja art. $103^{6}$ k.p.) ustawodawca pozostawia uzgodnienie poziomu takiego „ułatwiania” porozumieniu zawartemu pomiędzy pracownikiem a pracodawca. W sytuacji, gdy dochodzi do podnoszenia kwalifikacji z inicjatywy lub za zgoda pracodawcy, art. $103^{1}$ k.p. wskazuje minimalny poziom uprawnień pracownika. W jednym i drugim przypadku wyższy poziom uprawnień (który możemy już określić nie jako „nieprzeszkadzanie”, ale wspieranie pracownika) może wynikać z porozumienia zawartego pomiędzy stronami stosunku pracy. I tu dochodzimy do kwestii, która wydaje mi się sednem problemu - pracownik na stanowisku kierowniczym, wykształcony, posiadający doświadczenie zawodowe - taki, którego możemy określić jako kluczowego dla pracodawcy, ma pozycję negocjacyjna, pozwalającą mu w indywidualnym porozumieniu określić zasady wsparcia pracodawcy (np. w zakresie finansowania nauki, pomocy naukowych, dojazdu czy zakwaterowania podczas nauki). Pracownik ze wskazanych grup problemowych - przede wszystkim starszy lub nisko wykształcony o niskim poziomie kompetencji takiej możliwości obiektywnie nie ma. Jak długo prawo pracy będzie postrzegało problematykę podnoszenia kwalifikacji zawodowych głównie w perspektywie indywidualnej, tak długo -moim zdaniem - nie znajdzie odpowiedzi, jak wesprzeć w tym zakresie ogół pracowników.

Zdaniem A. Więcek obecnie mamy do czynienia z faktycznym przerzuceniem na samych pracowników ciężaru dbałości o zdobywanie i uzupełnianie wiedzy oraz umiejętności podnoszących kwalifikacje zawodowe ${ }^{50}$. Można postawić tezę, że jedynie pracownicy „cenni dla pracodawcy" radzą sobie w tych okolicznościach.

50 A. WIĘCEK, Podnoszenie kwalifikacji zawodowych - prawo czy obowiazek pracownika, [w:] Współczesne problemy prawa pracy i ubezpieczeń społecznych, red. 
Jak już wskazałam, w polskiej regulacji tworzenie funduszu szkoleniowego przez pracodawcę (lub kilku pracodawców), przewidziane w art. 67 ustawy o promocji zatrudnienia i instytucjach rynku pracy, ma charakter dobrowolny. Badania poszczególnych sektorów pokazuja że ilość funduszy szkoleniowych, stworzonych w oparciu o wskazaną ustawę, jest znikoma. Nie następuje także dofinansowanie szkoleń organizowanych przez pracodawców ze środków Funduszu Pracy ${ }^{51}$. Należy przyjrzeć się w tym miejscu, jaki jest wpływ polskich partnerów społecznych na wydatkowanie środków z Funduszu Pracy.

Rady zatrudnienia występują na trzech poziomach (art. 22 ust. 1, 2,3 , ustawy o promocji zatrudnienia i instytucjach rynku pracy). Ustawodawca przewiduje funkcjonowanie Naczelnej Rady Zatrudnienia, będącej organem opiniodawczo-doradczym ministra właściwego do spraw pracy w sprawach polityki rynku pracy. Wojewódzkie rady zatrudnienia są organami opiniodawczo-doradczymi marszałka województwa, natomiast powiatowe rady zatrudnienia są organami służącymi wsparciem staroście. W skład Naczelnej Rady Zatrudnienia wchodzą przedstawiciele wszystkich organizacji związkowych i organizacji pracodawców reprezentatywnych w rozumieniu ustawy o Trójstronnej Komisji do Spraw Społeczno-Gospodarczych i wojewódzkich komisjach dialogu społecznego ${ }^{52}$. W podobny sposób skon-

L. Florek, Ł. PISARCZYK, Warszawa 2011, s. 268; autorka zwraca uwagę, że odmiennie przedstawia się sytuacja pracowników zatrudnionych w służbie publicznej.

${ }^{51}$ Przykładowo badania przeprowadzane przez NSZZ Solidarność i BPI Polska w branży hutniczej wskazują, że w ani jednej hucie nie działa fundusz szkoleniowy w rozumieniu ustawy i nie ma ani jednego przypadku wykorzystania mechanizmu finansowania z art. 69 ustawy o promocji; A. KwIATKIEwICZ, Kwalifikacje zawodowe dziś i jutro - badanie adaptacyjności przedsiębiorstw i pracowników w sektorze hutnictwa stali, Warszawa 2011.

${ }^{52}$ Obok przedstawicieli partnerów społecznych w skład Naczelnej Rady Zatrudnienia wchodzą przedstawiciele ogólnopolskich organizacji jednostek samorządu terytorialnego reprezentowanych w Komisji Wspólnej Rządu i Samorządu Terytorialnego, przedstawiciele wojewódzkich rad zatrudnienia, przedstawiciele organizacji pozarządowych o zasięgu krajowym zajmujących się statutowo problematyką rynku pracy oraz przedstawiciele nauki - delegowani przez Komitet Nauk o Pracy i Polityce Społecznej Polskiej Akademii Nauk. 
struowane są składy wojewódzkich i powiatowych rad zatrudnienia ${ }^{53}$. Zgodnie z art. 23 ust. 4, członków Naczelnej Rady Zatrudnienia powołuje minister do spraw pracy, członków wojewódzkich rad zatrudnienia - marszałek województwa, a członków powiatowych rad zatrudnienia - starosta.

Rady zatrudnienia winny spełniać ważną funkcję, tworząc platformę współpracy partnerów społecznych, zmierzającą do poprawy warunków promowania produktywnego zatrudnienia i zmniejszania bezrobocia oraz poprawy efektywności programów rynku pracy i sprawności urzędów pracy ${ }^{54}$. Jednakże badania z połowy lat 90 . ubiegłego wieku, mające na celu ocenę efektywności działania rad zatrudnienia, sugerowały dużą skalę formalizmu, działań pozornych, mały udział w ich pracach niezależnych ekspertów ${ }^{55}$. Badania pokazują dużą pasywność członków $\operatorname{rad}^{56}$.

\section{WNIOSKI}

Porównując rolę związków zawodowych w państwach Europy Zachodniej i w Polsce, widzimy wyraźne różnice. Po pierwsze, różnica ta dotyczy roli układów zbiorowych pracy, a w szczególności ponadzakładowych układów zbiorowych. To swoiste źródło prawa pracy w Polsce wciąż nie odgrywa roli porównywalnej z rolą pełnioną w państwach starej Unii. Co więcej, związki zawodowe w Polsce bagatelizują w procesie negocjacji z pracodawcą możliwość ujmowania

${ }^{53}$ Partnerami społecznymi wchodzącymi w skład wojewódzkich rad zatrudnienia są przedstawiciele wojewódzkich struktur każdej organizacji związkowej i organizacji pracodawców reprezentatywnej w rozumieniu ustawy o Trójstronnej Komisji do Spraw Społeczno-gospodarczych, zaś w skład powiatowej rady zatrudnienia wchodzą przedstawiciele struktur terenowych.

${ }^{54}$ M. Kabaj, Strategie i programy przeciwdziałania bezrobociu w Unii Europejskiej i w Polsce, Warszawa 2004 s. 275.

55 M. KabaJ, op. cit., s. 227.

${ }^{56}$ L. Karwowski, Kształcenie ustawiczne jako element rynku pracy, [w:] Polskie szkolnictwo wyższe w procesie budowania Europejskiego społeczeństwa Wiedzy, red. G. Światowy, Wrocław 2001, s. 258. 
w układach zbiorowych pracy zagadnień dotyczących podnoszenia kwalifikacji zawodowych. Druga płaszczyzna to uczestnictwo w zarządzaniu funduszem szkoleniowym na poziomie zakładu pracy, branży czy na poziomie kraju. Nieobowiązkowy fundusz szkoleniowy, przewidziany w ustawie o promocji zatrudnienia i instytucjach rynku pracy, jest instrumentem ukierunkowanym jednocześnie w stronę zwiększenia finansowego zaangażowania pracodawcy w szkolenia oraz zwiększenia udziału związków zawodowych w zarządzaniu szkoleniami. Jest to rozwiązanie idace w dobrym kierunku, aczkolwiek niewystarczające. Należy także podkreślić, że obecność problematyki szkoleń w innych porozumieniach zbiorowych (takich, jak porozumienia zawierane ze względu na zwolnienia grupowe, porozumienia zawierane w trakcie sporu zbiorowego czy pakiety socjalne) w dużej mierze zależy od determinacji związków zawodowych. Ich zaangażowanie wydaje się być jednak wciąż śladowe.

Związki zawodowe przywiązane do wizji stabilnego zatrudnienia mają problemy z akceptacją tezy, że zwiększeniu mobilności zawodowej służy wsparcie udzielone pracownikom w postaci kształcenia zawodowego, które nie tylko wzmocni ich pozycję na rynku pracy, ale także umożliwi znalezienie innego zatrudnienia w sytuacji, w której dojdzie do zwolnienia pracownika ${ }^{57}$. Można postawić pytanie, na ile w polityce związków zawodowych widać przekonanie, że zachowanie miejsc pracy może odbywać się w drodze podnoszenia, doskonalenia czy uzupełniania kwalifikacji zawodowych pracowników ${ }^{58}$.

Nie można jednak postrzegać tego problemu jednostronnie. Po stronie polskich organizacji pracodawców także nie widać szczególnego zaangażowania do negocjowania omawianych zagadnień. Niskie zainteresowanie polskich pracodawców szkoleniem pracowników może być wytłumaczone między innymi faktem, że w porównaniu do innych państw UE kieruje się do nich relatywnie mało instrumentów wsparcia kształcenia ustawicznego. Dotyczy to nie tylko zachęt finansowych,

57 Ustawa o promocji zatrudnienia i instytucjach rynku pracy... s. 425.

58 L. FLOREK, Ochrona miejsc pracy a interesy pracowników, pracodawców i bezrobotnych, [w:] Prawo pracy a bezrobocie, red. L. Florek, Warszawa 2003, s. 20. 
ale i braku odpowiedniego doradztwa ${ }^{59}$. Zwraca się także uwagę, że lawinowy przyrost usług edukacyjnych finansowanych głownie ze środków unijnych powoduje zamęt wśród małych i średnich pracodawców, wywołany także faktem niskiej jakości oferowanych usług ${ }^{60}$.

M. Skapski zadaje pytanie, czy regulacji prawnej winno stawiać się wymóg mobilizacji podmiotów do zadań, które mają służyć ich dobru, jeżeli same zainteresowane strony nie są skłonne do ich podjęcia. Czy nie należy pozostawić tej problematyki swobodnej ocenie pracownika i pracodawcy, którzy będą kierować się swoimi interesami? Autor zwraca uwagę, że ze względów ogólnospołecznych odpowiedź powinna być przecząca. Jeżeli nawet z punktu widzenia mikroekonomicznego może być korzystne dla danego przedsiębiorstwa rozwiązanie umowy o pracę z pracownikiem nieposiadającym oczekiwanych w danym momencie kwalifikacji i poprzez proces rekrutacji znalezienie osoby o preferowanych kwalifikacjach, to z punktu widzenia ogólnospołecznego należy zwrócić uwagę, że żadna z dwóch osób biorących udział $\mathrm{w}$ tym procesie nie podnosi swoich kwalifikacji, a więc nie zmniejsza się niedopasowanie strukturalne na rynku pracy. Zdaniem autora, prawna regulacja podnoszenia kwalifikacji zawodowych przez pracowników realizować powinna dwa główne cele:

- określenie ram prawnych (obowiązków stron) organizacji podnoszenia kwalifikacji zawodowych;

- motywowanie do podejmowania inwestycji szkoleniowych w zakładach pracy.

Według M. Skąpskiego, o ile obecnie obowiązujące regulacje zawarte w kodeksie pracy wypełniają zadanie z obszaru pierwszego, to nie są przykładem dobrych rozwiązań w zakresie drugiego celu ${ }^{61}$.

W literaturze zwraca się uwagę, że politykę państwa w obszarze kształcenia ustawicznego, szczególnie nakierowaną na osoby o niskim dotychczasowym poziomie kwalifikacji, mogą skutecznie wspierać

59 H. Dąbrowski, M. Lis, K. Pogorzelski, op. cit., s. 156.

${ }^{60}$ Edukacja dla pracy. Raport o rozwoju społecznym, red. U. SzTANDERSKA, E. Drogosz-ZabŁocka, B. Minkiewicz, Warszawa 2007.

${ }^{61}$ M. SKĄPSKI, Funkcje prawnej regulacji..., s. 250 i 258. 
partnerzy społeczni zarówno na szczeblu centralnym, jak i branżowym. Podkreśla się, że partnerzy społeczni posiadają pełniejszą wiedzę co do potrzeb szkoleniowych. Związki zawodowe wpływają na politykę szkoleniową tak ukształtowana, by obejmowała ona również pracowników najsłabiej wykwalifikowanych i zawierała szkolenia ogólnorozwojowe ${ }^{62}$.

Należy przeanalizować, czy w polskim modelu stosunków przemysłowych jest możliwe zwiększenie ilości rokowań (zakładowych, branżowych, trójstronnych w Trójstronnej Komisji), które w jakimś stopniu odpowiedziałyby na problemy dostrzegane w Polsce. A są nimi: niski poziom uczestnictwa w kształceniu ustawicznym, selektywność tego procesu oraz niski poziom zaangażowania pracodawców, wynikający w dużej mierze z braku dostępnego profesjonalnego doradztwa, uświadamiającego, jak zwiększyć konkurencyjność przedsiębiorstwa poprzez inwestycje w zasoby ludzkie.

Regulacje prawne, dotyczące podnoszenia kwalifikacji pracowników, realizują jedną z podstawowych współczesnych funkcji prawa pracy - funkcję promocyjną (funkcję promocji zatrudnienia) ${ }^{63}$. Stąd tym istotniejsze powinno być zaangażowanie partnerów społecznych w tę problematykę. Jest jeszcze głębsza przyczyna. Wydaje się, że zintensyfikowanie dialogu dotyczącego kwalifikacji zawodowych mogłoby doprowadzić do pewnego ożywienia dwustronnych relacji na poziomie sektorowym, czyli elementu wyraźnie brakującego w polskich stosunkach przemysłowych ${ }^{64}$.

Zasadne jest jednak pytanie, czy w polskich warunkach jest w ogóle możliwe zwiększenie roli mechanizmów zbiorowych jako instrumentu oddziaływania w obszarze podnoszenia kwalifikacji zawodowych.

${ }^{62}$ P. JARVIS, The Rutledge International Handbook of Lifelong Learning, New York, 2009.

${ }^{63}$ M. SKąPSKI, Funkcje prawnej regulacji..., s. 257; na temat funkcji promocyjnej prawa pracy zob. Tenże, Ochronna funkcja prawa pracy $w$ gospodarce rynkowej, Kraków 2006, s. 106-162.

${ }^{64}$ B. Surdykowska, Kwalifikacje dla nowoczesności. Podnoszenie kwalifikacji zawodowych w Polsce, «Dialog. Pismo dialogu społecznego» 3/2010, s. 49. 
Należy zwrócić uwagę na dwa istotne czynniki uwarunkowujące obecny kształt zbiorowych stosunków pracy w Polsce. Po pierwsze, obserwujemy niewielki zasięg układów zbiorowych pracy (w szczególności tych o charakterze ponadzakładowym) oraz ich słabość jakościową (brakuje uzgodnień odbiegających in plus od regulacji legislacyjnych). Po drugie zaś, właściwie nie rozwija się w Polsce dialog dwustronny na poziomie krajowym, co tym samym ogranicza możliwość jego efektywnego wykorzystywania. Pewną nadzieję na poprawę sytuacji $\mathrm{w}$ odniesieniu do tego ostatniego czynnika stanowi powiązanie polskich partnerów społecznych z unijnym poziomem dialogu. Europejski dialog społeczny, który niedawno obchodził okrąłą dwudziestą rocznicę swego sformalizowanego istnienia, tworzy efekty będące impulsami do podejmowania autonomicznych działań przez związki zawodowe i organizacje pracodawców ${ }^{65}$. Jakkolwiek polskie doświadczenia we wdrożeniu dwóch porozumień dotyczących zagrożeń psychospołecznych nie napawają dużym optymizmem ${ }^{66}$ to istnieje pewna nadzieja, że proces implementacji najnowszego porozumienia o włączających rynkach pracy będzie dobrą płaszczyzną do gruntownej debaty o stworzeniu mechanizmów ułatwiających podnoszenie kwalifikacji zawodowych ${ }^{67}$.

W mojej ocenie, bez zmiany modelu wydatkowania środków z Funduszu Pracy, bez zwiększenia roli partnerów społecznych w wydatkowaniu jego środków, bez impulsu (np. z zakresu ulg podatkowych) ze strony ustawodawcy, warunkującego efektywne powstawanie funduszy szkoleniowych, nie jest możliwe zwiększenie ilości rokowań problematyki szkoleń pracowników w układach zbiorowych pracy. A co za tym idzie, kwestie te dalej będą widziane tak, jak dotychczasowo - głównie jako przedmiot indywidualnego prawa pracy, a nie zagadnienie zbiorowych interesów pracowniczych reprezentowanych przez przedstawicielstwo pracownicze. Oznacza to jednak, że polscy

65 S. AdAmczyK, Dylematy europejskiego dialogu społecznego, «MPP» 11/2011.

${ }^{66}$ B. Surdykowska, Dialog społeczny wokół zagrożeń psychospołecznych, «PiZS» 7/ 2011

${ }^{67}$ B. Surdyondska, Porozumienie europejskich partnerów spolecznych o inkluzyjnym rynku pracy, «MPP» 12/2010 
partnerzy społeczni nie będą w stanie wspólnie odnieść się do wyzwania związanego z kształceniem ustawicznym pracowników, które wskazywane jest w strategii „Europa 2020” jako jeden z najważniejszych elementów budowania nowoczesnej gospodarki.

\section{The Role of Trade Unions in the Enhancement of Employees' Qualifications}

\section{Summary}

The aim of this article is to discuss the enhancement of employees' qualifications as an area for the potential joint involvement of Polish trade unions and employers' organisations, and particularly for the assessment of the negotiability of solutions to remedy the current situation, which is giving rise to concern.

The author attempts to answer the question whether the policy pursued by Polish trade unions entails a commitment to the idea that the enhancement of professional qualifications may serve as an efficient tool to secure jobs. The same question is also put with respect to employers, who do not appear to be very interested in negotiating such issues or even in general in staff training, either. The attitude of diffidence may be explained by the fact that in comparison with the 15 member states of the pre-2004 EU, in Poland entrepreneurs receive a relatively low level of state support for continuing professional training for their staff. This observation applies not only to insufficient fiscal incentives but also to inadequate counselling services.

In the author's opinion collective bargaining on effective professional training and qualification enhancement programmes cannot be conducted without a profound transformation of the model for the allocation of financing from the Labour Fund. This should also entail raising the joint responsibility of employers and trade unions, which cannot be done unless an incentive in the form of tax relief on professional training courses comes from the legislator. Until such changes are introduced, the issue will continue to be perceived as it has been up to now - as a matter concerning an individual's right to work, not as the collective interest of employees represented by their trade unions. 